\title{
HUBUNGAN MENGKONSUMSI MAKANAN KARIOGENIK DAN POLA MENYIKAT GIGI DENGAN KEJADIAN KARIES GIGI PADA ANAK USIA SEKOLAH
}

\author{
Rahayu Setyaningsih', Luki Indra Asmara²
}

\begin{abstract}
Background: Dental caries are often found in school age, caused by consume cariogenic foods and wrong brush teeth pattern. Some foods like candy, chocholate, sweat breads can make children have a dental caries.

The Purpose : To determine the relationship between consume cariogenic food and brush teeth pattern with the incidence of dental caries in school age.

Subjects: The population in this study were all students at class I-III in SDN I and II Gedangan Sukoharjo as many as 205 students. The sample in this study is student at class I-III as many as 150 students used a sampling technique quota sampling.

Methods: This research is an analytical research design correlation to determine the relationship between consume cariogenic food and brrush teeth pattern with the incidence of dental caries in school.

Results: From the statistical test bivariate relationship of each independent variable and dependent variable using the chi-square test results $p: 0.001$. As for the results of multivariate statistical test values obtained Nagelkerke R Square of $56.6 \%$.

Conclusion: A variable level of consume cariogenic food and brush teeth pattern together can influence the incidence of dental caries in children school age of $56.6 \%$ and the remaining $43.4 \%$ influenced by other variables.
\end{abstract}

Keywords: Smoking, disruption of sleep patterns, teen age

\section{PENDAHULUAN}

Penelitian ini dilatarbelakangi oleh semakin meningkatnya kejadian karies gigi di sejumlah wilayah di Indonesia. Hasil laporan survai demografi dan kesehatan Indonesia tahun 2013 didapatkan peningkatan prevalensi terjadinya karies aktif pada penduduk Indonesia yaitu 43,3 \% (2007) menjadi 53,2 \% (2013). Hampir semua provinsi mengalami kenaikan prevalensi karies aktif dari tahun 2007 ke tahun 2013, hanya 4 provinsi yang mengalami penurunan, yaitu: Maluku Utara, Papua Barat, Yogyakarta dan Riau. Peningkatan tertinggi terdapat pada provinsi Sulawesi Selatan $(29,1 \%)$ dan Lampung (23,6 \%), yaitu 2 kali lebih peningkatan nasional $(9.8 \%)$. Di Jawa Tengah didapatkan sebanyak $27 \%$ pada anak usia $5-14$ tahun mengalami masalah kesehatan gigi dan mulut seperti karies gigi.

Karies gigi merupakan masalah utama kesehatan gigi dan mulut di dunia dan berperan penting pada masalah gigi pada anak. Karies gigi adalah kerusakan jaringan keras gigi yang disebabkan oleh asam yang ada dalam karbohidrat melalui perantara mikroorganisme yang ada dalam saliva (Irma dan Intan, 2013).

Banyak sekali faktor yang mempengaruhi terjadinya karies gigi. Dengan semakin canggihnya pabrik makanan, semakin tinggi juga persentase karies pada masyarakat yang mengkonsumsi makanan hasil pabrik tersebut. Beberapa hal yang dapat mempengaruhi terjadinya karies gigi yaitu karena faktor keturunan, ras, jenis kelamin, usia, vitamin, unsur kimia, air ludah, plak dan makanan. Makanan dan minuman yang bersifat fermentasi 
karbohidrat lebih signifikan memproduksi asam, diikuti oleh demineralisasi email. Tidak semua karbohidrat benar-benar kariogenik. Karbohidrat komplek seperti gandum relatif tidak berbahaya karena tidak secara sempurna dihancurkan di rongga mulut, tetapi molekul karbohidrat yang rendah dengan mudah bersatu dengan plak dan dimetabolisme secara cepat oleh bakteri (Tarigan, 2016).

Jenis makanan yang berdampak pada pembentukan terjadinya karies gigi adalah jenis makanan yang mengandung kariogenik seperti coklat, permen, kue dan makanan manis yang membuat anak-anak sangat rentan terhadap karies gigi. Hal ini dikarenakan makanan yang mengandung karbohidrat misalnya sukrosa dan gula atau makanan yang manis seperti coklat, permen dan kue yang mudah menempel pada gigi yang dapat diragikan oleh bakteri tertentu dan membentuk asam sehingga dapat menjadi plak dan merusak struktur gigi jika dibiarkan begitu saja dalam kurun waktu yang lama (Irma dan Intan, 2013). Sukrosa, glukosa dan fruktosa merupakan substrat yang dapat digunakan bakteri, tetapi diantara ketiga jenis hidrat arang ini, sukrosa merupakan substrat paling penting (Sodikin, 2011). Perhatian lebih diberikan untuk mengurangi jumlah, frekuensi pemasukan gula dan karbohidrat fermentasi (Duggal, Cameron dan Toumba, 2014).

Anak usia sekolah perlu menyikat gigi mereka dua sampai tiga kali per hari selama 2 sampai 3 menit setiap menyikat gigi dengan pasta gigi yang mengandung fluorinasi. Menggunakan teknik yang benar untuk menyikat gigi sangat penting dalam pencegahan gigi berlubang (Kyle dan Carman, 2015).

Terkadang perawatan gigi tidak dianggap penting karena gigi susu/ gigi primer akan digantikan oleh gigi permanen. Persepsi ini memicu komplikasi gigi permanen seperti maloklusi, suatu kondisi gigi yang menumpuk, tidak lurus, atau tidak sejajar (Kyle dan Carman, 2015). Menurut penelitian Permatasari dan Andhini (2014), yang berjudul hubungan perilaku menggosok gigi dan pola jajan anak dengan kejadian karies gigi pada murid SDN 157 Palembang. Hasil penelitian diperoleh pola jajan anak yang buruk cenderung tinggi 93\%, hal ini berpengaruh besar terhadap kejadian karies gigi anak, keadaan diperburuk dengan tingkat pengetahuan anak dalam menggosok gigi yang kurang sebanyak $59 \%$, sikap anak dalam menggosok gigi yang tidak mendukung $61 \%$, tindakan anak dalam menggosok gigi yang tidak baik 55\%. Hasil uji Chi Square ada hubungan yang bermakna antara perilaku menggosok gigi pada anak dengan kejadian karies gigi $(p<0.05)$ dan ada hubungan antara pola jajan anak dengan kejadian karies gigi $(p<0.05)$. Penelitian Setyaningsih dan Prakoso (2016) berjudul hubungan tingkat pendidikan, tingkat sosial ekonomi, dan tingkat pengetahuan orangtua tentang perawatan gigi dengan kejadian karies gigi pada anak usia balita di Desa Mancasan Baki Sukoharjo, berdasarkan uji statistik multivariat menunjukkan bahwa variabel tingkat pendidikan, sosial ekonomi dan tingkat pengetahuan secara bersama-sama mempengaruhi kejadian karies dengan Nagelkerke $R$ square $47.3 \%$. Penelitian Windarti (2016) dengan judul hubungan perilaku menggosok gigi dengan kejadian karies gigi pada anak usia 6-12 tahun di SDN 1 Tamanwinangun Kebumen, hasil penelitian menunjukkan perilaku menggosok gigi anak usia 6-12 tahun di SD Negeri 1 Tamanwinangun Kebumen tahun 2016 mayoritas kategori kurang baik $(44.44 \%)$, mayoritas mengalami 
kejadian karies gigi sedang (karies profundi) (39.68\%), terdapat hubungan signifikan antara perilaku menggosok gigi dengan kejadian karies gigi pada anak usia 6-12 tahun di SD Negeri 1 Tamanwinangun Kebumen tahun $2016(p=0.001)$. Penelitian Budisuari, Oktarina dan Mikrajab (2010) dengan judul hubungan pola makan dan kebiasaan menyikat gigi dengan kesehatan gigi dan mulut (karies) di Indonesia, hasil penelitian menunjukkan bahwa karakteristik seseorang (umur, pendidikan, tempat tinggal, sosial ekonomi) berhubungan dengan terjadinya karies. Pada variabel pendidikan dan tingkat sosial ekonomi ditemukan semakin tinggi tingkat pendidikan, dan tingkat sosial ekonomi ada kecenderungan semakin sedikit yang memiliki karies di atas rerata (>2). Uji Chi Square ada hubungan yang signifikan. Responden yang tinggal di kota beresiko terjadinya karies lebih besar dibandingkan yang tinggal di desa. Masyarakat yang sering mengkonsumsi makanan manis cenderung terjadinya karies lebih besar dibandingkan yang sering mengkonsumsi makanan berserat. Responden yang menyikat gigi mempunyai kecenderungan terjadinya karies lebih ringan dibandingkan yang tidak menyikat gigi. Penelitian Yuwan dan Nurwanto (2013) berjudul hubungan kejadian karies gigi dengan konsumsi makanan kariogenik dan status gizi pada anak sekolah dasar (studi pada anak kelas III dan IV SDN Kadipaten I dan II Bojonegoro). Hasil penelitian menunjukkan tingkat karies gigi sedang $23.8 \%$. Frekuensi konsumsi makanan kariogenik sebanyak $73 \%$ mengkonsumsi 3-6x sehari. Terdapat $15.8 \%$ anak memiliki status gizi sangat kurang. Hasil uji korelasi menunjukkan bahwa: ada hubungan antara kejadian karies gigi dengan konsumsi makanan kariogenik ( $p=0.009 ; r=0.298)$, ada hubungan antara karies gigi dengan status gizi $(p=0.008 ; r=0.303)$.

Bahwa penelitian ini merupakan replikasi dari penelitian terdahulu dengan perbedaan variabel yang sekarang yaitu tentang konsumsi makanan kariogenik dan pola menyikat gigi dengan kejadian karies gigi. Variabel yang diteliti saat ini untuk mengetahui faktor internal yaitu kebiasaan tentang makanan dan pola menyikat gigi sedangkan variabel terdahulu dari faktor eksternal yaitu tingkat pendidikan, tingkat sosial ekonomi dan tingkat pengetahuan orangtua tentang perawatan gigi.

Hasil survai pendahuluan di SDN I Gedangan didapatkan hasil bahwa murid yang mengalami karies gigi sebanyak 18 orang, sedangkan di SDN II Gedangan didapatkan hasil murid yang mengalami karies gigi sebanyak 17 orang. Kemudian setelah dilakukan wawancara didapat data bahwa sebagian besar anak suka mengkonsumsi makanan yang manis terutama permen dan coklat. Untuk kebiasaan menyikat gigi pada pagi hari hampir seluruh siswa melakukan setiap hari, tetapi untuk menyikat gigi pada malam hari terutama sebelum tidur hanya dilakukan oleh sebagian kecil. Berdasar uraian tersebut di atas serta belum adanya penelitian tentang hubungan mengkonsumsi makanan kariogenik dan pola menyikat gigi terhadap kejadian karies gigi pada anak usia sekolah di SDN I dan SDN II Gedangan, maka peneliti tertarik untuk melakukan penelitian tentang "Hubungan Mengkonsumsi Makanan Kariogenik dan Pola Menyikat Gigi dengan Kejadian Karies Gigi pada Anak Usia Sekolah di SDN I dan II Gedangan".

\section{TUJUAN PENELITIAN}

Untuk mengetahui hubungan 
mengkonsumsi makanan kariogenik dan pola menyikat gigi dengan kejadian karies gigi pada anak usia sekolah.

\section{METODE/DESAIN PENELITIAN}

Penelitian ini merupakan penelitian analitik dengan desain korelasi dan pendekatan cross sectional untuk mengetahui hubungan mengkonsumsi makanan kariogenik dan pola menyikat gigi dengan kejadian karies gigi pada anak usia sekolah.

\section{POPULASI, SAMPEL, DAN} TEKNIK SAMPLING

Populasi pada penelitian ini adalah seluruh murid kelas I - III SDN I dan II Gedangan Sukoharjo yang berjumlah 205 siswa. Sampel berdasarkan tabel Kretjie 150. Teknik sampling yang digunakan adalah teknik quota sampling.

\section{HASIL PENELITIAN}

Karakteristik responden orangtua diketahui berdasarkan umur, agama, tingkat pendidikan dan pekerjaan, sedangkan karakteristik balita berdasarkan jenis kelamin dan umur sebagai berikut:

Tabel 1. Karakteristik Responden

\begin{tabular}{|c|c|c|c|}
\hline $\begin{array}{l}\text { Karak- } \\
\text { teristik }\end{array}$ & $\begin{array}{l}\text { Kate- } \\
\text { gori }\end{array}$ & $f$ & $\%$ \\
\hline \multirow[t]{2}{*}{$\begin{array}{l}\text { Jenis } \\
\text { Kelamin }\end{array}$} & $\begin{array}{l}\text { Laki- } \\
\text { laki }\end{array}$ & 69 & 46 \\
\hline & $\begin{array}{l}\text { Perem- } \\
\text { puan }\end{array}$ & 81 & 54 \\
\hline \multirow[t]{4}{*}{ Umur } & 7 & 9 & 6 \\
\hline & $\begin{array}{l}8 \\
9\end{array}$ & $\begin{array}{l}10 \\
30\end{array}$ & $\begin{array}{l}72.7 \\
20\end{array}$ \\
\hline & 10 & 1 & 0.7 \\
\hline & 11 & 1 & 0.7 \\
\hline \multirow[t]{3}{*}{ Kelas } & 1 & 23 & 15.3 \\
\hline & 2 & 68 & 54.5 \\
\hline & 3 & 59 & 39.3 \\
\hline \multirow[t]{2}{*}{ Konsumsi } & $\mathrm{Ya}$ & 100 & 67.3 \\
\hline & Tidak & 50 & 33.3 \\
\hline Pola & Benar & 64 & 42.7 \\
\hline Sikat Gigi & Salah & 86 & 57.3 \\
\hline Karies & $\mathrm{Ya}$ & 102 & 68 \\
\hline Gigi & Tidak & 48 & 32 \\
\hline
\end{tabular}

Dari Tabel 1 diperoleh informasi bahwa 81 responden (54 \%) berjenis kelamin perempuan dan 69 responden (46\%) adalah berjenis kelamin laki-laki, jumlah responden terbanyak adalah usia 8 tahun yaitu 109 orang (72.7\%), jumlah responden terbanyak adalah kelas 2 yaitu 68 orang (45.4\%). Sebagian besar responden mengkonsumsi makanan kariogenik yaitu 100 orang (66.7\%), sebagian besar responden yang pola menyikat giginya salah sejumlah 86 orang $(57.3 \%)$.

Tabel 2.

Tabulasi Silang Hubungan

Mengkonsumsi Makanan Kariogenik dengan Kejadian Karies Gigi

\begin{tabular}{cccc}
\hline \multirow{2}{*}{$\begin{array}{c}\text { Makanan } \\
\text { Kariogenik }\end{array}$} & \multicolumn{2}{c}{ Karies Gigi } & \multirow{2}{*}{ Jml } \\
\cline { 2 - 3 } & Ya & Tidak & \\
\hline Ya & 90 & 10 & 100 \\
Tidak & 12 & 38 & 50 \\
\hline Jml & 102 & 48 & 150 \\
\hline
\end{tabular}

Tabel 2 menunjukkan terdapat responden yang mengkonsumsi makanan kariogenik yaitu 100 orang, dengan 90 orang yang mengalami karies gigi dan 10 orang tidak mengalami karies gigi.

Sedangkan responden yang tidak mengkonsumsi makanan kariogenik yaitu 50 orang, dengan 12 orang yang mengalami karies gigi dan 38 tidak mengalami karies gigi.

Berdasarkan hasil uji statistik bivariat dengan menggunakan chi square dengan $\alpha=5 \% \quad(0,05)$ diperoleh $p$ sebesar 0.000 sehingga $p<0.05$, yang berarti hipotesa diterima maka dapat ditarik kesimpulan bahwa ada hubungan menkonsumsi makanan kariogenik dengan terjadinya karies gigi. 
Tabel 3.

Tabulasi Silang Hubungan Pola Menyikat Gigi dengan Kejadian Karies Gigi

\begin{tabular}{lccc}
\hline \multirow{2}{*}{$\begin{array}{l}\text { Pola Sikat } \\
\text { Gigi }\end{array}$} & \multicolumn{3}{c}{ Karies Gigi } \\
\cline { 2 - 3 } & Ya & Tidak & \\
\hline Benar & 27 & 37 & 64 \\
Salah & 75 & 11 & 86 \\
\hline Jml & 102 & 48 & 150 \\
\hline
\end{tabular}

Tabel 3 menunjukkan terdapat responden yang pola sikat giginya salah yaitu 86 orang, dengan 75 orang yang mengalami karies gigi dan 11 orang tidak mengalami karies gigi.

Sedangkan responden yang pola sikat giginya benar yaitu 64 orang, dengan 27 orang yang mengalami karies gigi dan 37 tidak mengalami karies gigi.

Berdasarkan hasil uji statistik bivariat dengan menggunakan $\mathrm{Chi}$ Square dengan $\alpha=5 \% \quad(0.05)$ diperoleh $p$ sebesar 0.000 sehingga $p<0.05$, yang berarti hipotesa diterima maka dapat ditarik kesimpulan bahwa ada hubungan pola menyikat gigi dengan terjadinya karies gigi.

Tabel 4.

Hasil Analisis Multivariat Regresi Logistik Ganda antara Konsumsi Makanan Kariogenik dan Pola Menyikat Gigi dengan Kejadian Karies Gigi

\begin{tabular}{lcc}
\hline \multicolumn{1}{c}{$\begin{array}{l}\text { Variabel } \\
\text { Independen }\end{array}$} & OR & P \\
\hline $\begin{array}{l}\text { Konsumsi } \\
\text { Kariogenik }\end{array}$ & 18.9 & 0.00 \\
Pola Sikat Gigi & 4.6 & 0.02 \\
\hline Nagelkerke $R$ Square $56.6 \%$ & \\
\hline
\end{tabular}

Berdasarkan tabel di atas dapat dilihat bahwa :

Adanya hubungan yang positif dan signifikan antara mengkonsumsi makanan kariogenik dengan karies gigi pada anak usia sekolah. Responden yang mengkonsumsi makanan kariogenik beresiko mengalami karies gigi 18 kali lebih tinggi daripada responden yang tidak mengkonsumsi makanan kariogenik. (OR = $18.92 ; p=0.000)$. Adanya hubungan yang positif dan signifikan antara pola menyikat gigi dengan karies gigi pada anak usia sekolah. Responden yang pola sikat giginya salah beresiko untuk mengalami karies gigi 4 kali lebih tinggi daripada responden yang pola sikat giginya benar $(O R=4.68$; $p=0.002$ ).

Bahwa hasil penelitian menunjukkan variabel independen secara bersama-sama mempengaruhi variabel dependen dapat dilihat pada nilai Nagelkerke $R$ Square $56.6 \%$ artinya bahwa mengkonsumsi makanan kariogenik dan pola menyikat gigi mampu mempengaruhi kejadian karies gigi pada anak usia sekolah sebesar $56.6 \%$ dan sisanya $43.4 \%$ dipengaruhi oleh variabel lain di luar penelitian.

\section{PEMBAHASAN}

Dari Tabel 1 dapat diketahui bahwa sebagian besar responden mengkonsumsi makanan kariogenik yaitu 100 orang (66.7\%). Makanan kariogenik adalah makanan yang berdampak pada pembentukan terjadinya karies gigi yang membuat anak-anak sangat rentan terhadap karies gigi. Hal ini dikarenakan makanan yang mengandung karbohidrat misalnya sukrosa dan gula atau makanan yang manis yang mudah menempel pada gigi yang dapat diragikan oleh bakteri tertentu dan membentuk asam sehingga dapat menjadi plak dan merusak struktur gigi jika dibiarkan begitu saja dalam kurun waktu yang lama (Irma dan Intan, 2013). Jenis makanan yang sering dikonsumsi oleh anak-anak di SDN I dan II Gedangan ini berupa manisan, coklat, permen, susu, biskuit dimana makanan ini mengandung hidrat 
arang, sukrosa dan glukosa yang cukup tinggi. Hal ini sesuai dengan pendapat dari Beck (2011), jenis makan kariogenik meliputi : minuman manis, kue-kue basah yang manis, makanan manis yang lengket, seperti coklat, dodol, makanan manis yang kering seperti biskuit, permen yang keras, kue-kue kering. Sementara itu menurut Sodikin (2011) bakteri kariogenik akan memetabolisme hidrat arang sebagai sumber energi, masingmasing hidrat arang sukrosa, glukosa, dan fruktosa merupakan substrat yang dapat digunakan bakteri, tetapi diantara ketiga jenis hidrat arang ini, sukrosa merupakan substrat paling penting. Jumlah makanan yang tinggi sukrosa dan glukosa ini dikonsumsi oleh anakanak di SDN I dan II Gedangan lebih dari sekali dalam sehari. Dari 100 responden yang mengkonsumsi makanan kariogenik ini 94 diantaranya mengkonsumsi lebih dari sekali dalam sehari. Padahal menurut Beck (2011), kariogenitas pada suatu makanan tergantung pada bentuk fisik seperti makanan yang lengket akan melekat pada permukaan gigi dan terselip di dalam celah-celah gigi sehingga merupakan makanan yang paling merugikan kesehatan gigi. Kekerapan konsumsi setelah makan makanan yang mengandung sukrosa, $\mathrm{pH}$ mulut turun dalam waktu 2.5 menit dan tetap rendah sampai selama satu jam. Ini berarti jika gula pasir dikonsumsi tiga kali sehari, $\mathrm{pH}$ mulut selama sekitar tiga jam akan berada di bawah 5.5.

Dapat diketahui bahwa sebagian besar responden pola menyikat giginya salah yaitu 86 orang $(57.3 \%)$, sedangkan 64 orang $(42.7 \%)$ pola menyikat giginya benar. Menurut Duggal, Cameron dan Toumba (2014), tata cara menyikat gigi adalah sebagai berikut waktu mulai menyikat gigi, tingkat karies lebih rentan ketika gigi sudah mulai disikat dengan pasta gigi berfluoride sebelum anak berusia 1 tahun. Direkomendasikan untuk memulai menyikat gigi anak sedini mungkin saat gigi mulai bererupsi. Frekuensi menyikat gigi, tingkat karies lebih rendah saat menyikat gigi dilakukan dua kali sehari dibandingkan hanya sekali sehari. Dari hasil penelitian didapatkan dalam hal frekuensi menyikat gigi sebanyak 45 responden menyikat gigi kurang dari 2 kali dalam sehari. Frekuensi terbanyak dilakukan sekali hanya pada waktu pagi hari jarang yang melakukan sikat gigi di malam hari. Idealnya, menyikat gigi sebaiknya dilakukan di pagi hari dan malam hari sebelum tidur, waktu menyikat gigi, idealnya menyikat gigi berfluoride dilakukan pagi hari sebelum sarapan. Dari hasil penelitian didapatkan waktu dalam menggosok gigi lebih banyak dilakukan pada saat mandi pagi hari sebelum sarapan, yang dilakukan oleh 34 responden, cara menggosok gigi tersebut sudah benar akan tetapi mereka hanya melakukan gosok gigi hanya di pagi hari saja sedangkan malam hari tidak melakukan gosok gigi. Sedangkan cara yang salah dilakukan oleh 32 responden. Menurut Erwana (2013), cara menggosok gigi yang benar adalah sebagai berikut gerakan untuk bagian luar gigi depan adalah ke atas dan ke bawah jangan disikat dengan gerakan menyamping bolakbalik karena bisa menyebabkan gusi menjadi rusak. Bagian luar gigi belakang jangan disikat dengan gerakan naik turun, tetapi dengan gerakan maju mundur atau memutar. Gerakan naik turun tidak efektif membersihkan gigi belakang bagian luar. Untuk bagian dalam dari gigi depan dan belakang harus disikat dengan gerakan menarik. Fluoride akan tersedia sebelum terpapar asam, sehingga akan menyebabkan kehilangan mineral gigi karena enamel yang sedang 
lunak akibat paparan asam akan tergerus.

Dapat diketahui bahwa sebagian besar responden mengalami karies gigi yaitu 102 orang (68\%), sedangkan 48 orang (32\%) tidak mengalami karies gigi. Karies gigi adalah kerusakan jaringan keras gigi yang disebabkan oleh asam yang ada dalam karbohidrat melalui perantara mikroorganisme yang ada dalam saliva (Isro'in dan Andarmoyo, 2012). Pada awal serangan lesi berupa bercak putih, kemudian berkembang menjadi berwarna coklat kehitaman (plaque). Nyeri atau linu merupakan keluhan yang sangat sering. Rasa nyeri hebat disertai dengan pembengkakan dan limfedenopati regional merupakan tanda adanya komplikasi pulpitis. Manifestasi klinis yang paling sering ditemukan berupa rasa nyeri hebat, pembengkakan, bau mulut tidak enak, keluarnya nanah lewat gusi dan sebagainya (Diyono dan Mulyanti, 2013). Dari hasil penelitian, 102 responden yang mengalami karies gigi ditemukan sebanyak 80 responden mengalami bercak kehitaman pada gigi (plak), 65 responden mengalami lubang pada gigi dan 35 responden mengalami nyeri gigi.

Jika dikaitkan antara mengkonsumsi makanan kariogenik dengan proses karies gigi maka pada tabel 2 didapatkan responden yang mengkonsumsi makanan kariogenik sejumlah 100 orang mengkonsumsi makanan kariogenik 90 orang mengalami karies gigi, hal ini sangat dimungkinkan karena menurut Tarigan (2016), terjadinya karies gigi berdasarkan teori proteolitik adalah adanya bakteri yang ada di dalam rongga mulut mempunyai kemampuan memproduksi yang sangat cepat bila suasana atau lingkungan gigi banyak mengandung karbohidrat. Produk dari mikroorganisme ini adalah dibentuknya enzim-enzim proteolitik dan toksin-toksin mikroorganisme. Adanya zat proteolitik ini akan menyebabkan terjadinya penguraian dan erosi dari jaringan gigi. Produk enzim ini juga bersifat sangat asam, dan biasanya akan membentuk pigmentasi kuning pada gigi.

Dari hasil uji statistik dengan chi square diperoleh $p<0.001$ sehingga dapat disimpulkan bahwa ada hubungan antara mengkonsumsi makanan kariogenik dengan terjadinya karies gigi. Hal ini sesuai dengan penelitian Yuwan dan Nurwanto (2013), hasil penelitian menunjukkan frekuensi konsumsi makanan kariogenik sebanyak $73 \%$ mengkonsumsi 3-6x sehari. Hasil uji korelasi menunjukkan bahwa: ada hubungan antara kejadian karies gigi dengan konsumsi makanan kariogenik ( $p=0.009 ; r=0.298)$.

Keterkaitan antara pola menyikat gigi dengan karies gigi adalah pada tabel 3 ditemukan bahwa responden yang pola menyikat giginya salah sejumlah 86 orang, 75 diantaranya menderita karies gigi. Cara sikat gigi yang tidak benar menyebabkan makanan yang menempel tidak bisa dibersihkan secara sempurna sehingga menyebabkan faktor perusak secara aktif. Faktor ini menyebabkan terjadinya demineralisasi yang bisa berasal dari makanan, saliva, bakteri, bahan gigi. Proteolisis dapat disebabkan oleh enzim yang dihasilkan oleh Streptococus. Proses ini menimbulkan terjadinya plak pada gigi, padahal plak pada gigi memudahkan melekatnya bakteri. Apabila pola menyikat gigi salah baik dalam cara dan waktu maka akan menimbulkan karies gigi. Dari hasil uji statistik menggunakan $\mathrm{Chi}$ Square diperoleh $p<0.001$ sehingga dapat disimpulkan bahwa ada hubungan antara pola menyikat gigi dengan terjadinya karies gigi. Hal ini sesuai dengan penelitian Windarti (2016), hasil penelitian 
menunjukkan perilaku menggosok gigi anak usia 6-12 tahun di SD Negeri 1 Tamanwinangun Kebumen tahun 2016 mayoritas kategori kurang baik (44.44\%), mayoritas mengalami kejadian karies gigi sedang (karies profundi) (39.68\%), terdapat hubungan signifikan antara perilaku menggosok gigi dengan kejadian karies gigi pada anak usia 6-12 tahun di SD Negeri 1 Tamanwinangun Kebumen tahun $2016(p=0.001)$.

Hasil penelitian menunjukkan variabel independen secara bersama-sama mempengaruhi variabel dependen. Hal ini dapat dilihat dari nilai Nagelkerke $R$ Square $56.6 \%$ analisis dengan model regresi logistik ganda. Variabel independen yang dimasukkan dalam model adalah konsumsi makanan kariogenik dan pola menyikat gigi secara bersamaan mampu mempengaruhi variabel dependen yaitu karies gigi, maka dapat disimpulkan bahwa variabel independen secara bersama-sama yaitu mengkonsumsi makanan kariogenik dan pola menyikat gigi berpengaruh terhadap variabel dependen yaitu karies gigi. Adanya hubungan yang positif dan signifikan antara mengkonsumsi makanan kariogenik dengan karies gigi pada anak usia sekolah. Responden yang mengkonsumsi makanan kariogenik beresiko mengalami karies gigi 18 kali lebih tinggi daripada responden yang tidak mengkonsumsi makanan kariogenik (OR $=18.92 ; \mathrm{p}=0.000$ ). Adanya hubungan yang positif dan signifikan antara pola menyikat gigi dengan karies gigi pada anak usia sekolah. Responden yang pola sikat giginya salah beresiko untuk mengalami karies gigi 4 kali lebih tinggi daripada responden yang pola sikat giginya benar $(\mathrm{OR}=4.68$; $\mathrm{p}=0.002)$. Beberapa faktor yang mempengaruhi terjadinya karies gigi pada anak antara lain, faktor makanan, kebersihan mulut, dan kebiasaan buruk pada anak bahwa ada hubungan antara frekuensi konsumsi karbohidrat, frekuensi pemasukan karbohidrat merupakan faktor penentu yang lebih penting pada kejadian karies gigi daripada jumlah karbohidrat yang dikonsumsi. Karbohidrat dipertimbangkan sebagai bahan tunggal terpenting dari penyebab kebusukan pada gigi, bau mulut, gigi berlubang tetapi yang terpenting adalah frekuensi kuantitas total (Sodikin, 2011).

Faktor pencegahan karies gigi, dalam pencegahan karies gigi, ada empat faktor penting yaitu pemberian fluorida untuk menguatkan gigi, sikat gigi yang efisien untuk melepaskan plak pada gigi, dan perawatan gigi yang teratur. Hal ini sesuai dengan penelitian Budisuari, Oktarina dan Mikrajab (2010), hasil penelitian menunjukkan bahwa karakteristik seseorang (umur, pendidikan, tempat tinggal, sosial ekonomi) berhubungan dengan terjadinya karies. Uji chi square ada hubungan yang signifikan. Sesuai juga dengan penelitian Permatasari dan Andhini (2014), hasil penelitian diperoleh pola jajan anak yang buruk cenderung tinggi 93\%, hal ini berpengaruh besar terhadap kejadian karies gigi anak. Hasil uji Chi Square menunjukkan bahwa ada hubungan yang bermakna antara perilaku menggosok gigi pada anak dengan kejadian karies gigi $(p<0.05)$.

\section{KESIMPULAN}

1. Frekuensi paling banyak pada konsumsi makanan adalah kariogenik yaitu $66.7 \%$.

2. Frekuensi pola menyikat gigi salah yaitu sebesar $57.3 \%$.

3. Frekuensi paling banyak menderita karies gigi yaitu sebesar $68.0 \%$.

4. Hasil uji analisa bivariat diperoleh $p<0,001$ sedangkan analisa 
mulitivariat diperoleh nilai Nagelkerke R56.6\%.

\section{SARAN}

1. Orangtua, guru dan tenaga kesehatan disarankan untuk mensosialisasikan jenis makanan yang sehat untuk dikonsumsi oleh anak usia sekolah dengan cara mengajarkan pada anak untuk memilih jenis makanan yang sehat agar terhindar dari karies gigi.

2. Bagi anak dengan pola menyikat gigi yang salah, orangtua disarankan untuk berusaha menyediakan perawatan gigi minimal bagi anaknya dengan cara menyediakan sikat gigi dan pasta gigi yang sesuai dengan usia anak serta mengajarkan waktu, cara dan frekuensi yang benar tentang menggosok gigi.

\section{DAFTAR PUSTAKA}

Beck, M. E. 2011. IImu Gizi dan Diet Hubungannya dengan Penyakit-penyakit untuk Perawat dan Dokter. Alih bahasa Kristianti. CV Andi Offset, Yogyakarta.

Badan Pusat Statistik. 2013 Laporan Survey Demografi dan Kesehatan Indonesia. BPS Kemenkes Macrolnc, Jakarta.

Budisuari, M. A., Oktarina dan M. A. Mikrajab. Hubungan Pola Makan dan Kebiasaan Menyikat Gigi dengan Kesehatan Gigi dan Mulut (Karies) di Indonesia. Buletin Penelitian Sistem Kesehatan. Vol 13 No 1 Januari 2010. http://ejournal.litbang.depkes.g o.id/index.php/hsr/article/view/ 2760/1518

Diyono dan S. Mulyanti. 2013. Buku Ajar Keperawatan Medikal Bedah Sistem Pencernaan (Dilengkapi Contoh Studi Kasus dengan Aplikasi NNN (NANDA NOC NIC)). Kencana
Prenada Media Group, Jakarta.

Duggal, M., A. Cameron dan J. Toumba. 2014. At a Glance Kedokteran Gigi Anak. Alih bahasa Mirza Aryanto. Erlangga, Jakarta.

Erwana, A. F. 2013. Seputar Kesehatan Gigi dan Mulut. Rapha Publishing, Yogyakarta.

Irma, Z. Indah dan S. A. Intan. 2013. Penyakit Gigi, Mulut dan THT. Nuha Medika, Yogyakarta.

Isro'in, L. dan S. Andarmoyo. 2012. Personal Hygiene. Graha IImu, Yogyakarta.

Kyle, T. dan S. Carman. 2015. Buku Ajar Keperawatan Pediatri. Alih bahasa Devi Yulianti. Penerbit Buku Kedokteran EGC, Jakarta.

Permatasari, I. dan D. Andhini. 2014. "Hubungan Perilaku Menggosok Gigi dan Pola Jajan Anak Dengan Kejadian Karies Gigi pada Murid SD Negeri 157 Palembang". Jurnal Keperawatan Sriwijaya. 1.

https://media.neliti.com/media/ publications/181735-IDhubungan-perilakumenggosok-gigi-dan-pol.pdf. Diakses tanggal 18 September 2017.

Setyaningsih, R. dan I. Prakoso. 2016. "Hubungan Tingkat Pendidikan, Tingkat Sosial Ekonomi dan Tingkat Pengetahuan Orang Tua tentang Perawatan Gigi dengan Kejadian Karies Gigi pada Anak Usia Balita di Desa Mancasan Baki Sukoharjo". Jurnal IImu Kesehatan Kosala Volume 4. Nomor 1. Surakarta.

Sodikin. 2011. Asuhan Keperawatan Anak: Gangguan Sistem Gastrointestinal dan Hepatobilier. Salemba Medika, Jakarta. 
Tarigan, R. 2016. Karies Gigi. Penerbit Buku Kedokteran EGC, Jakarta.

Yuwan, Nana dan Nuyanto. Hubungan Kejadian Karies Gigi dengan Konsumsi Makanan Kariogenik dan Status Gizi pada Sekolah Dasar. Diakses tanggal 2 Januari 2018.

Windarti. 2016. Hubungan Perilaku Menggosok Gigi Dengan Kejadian Karies Gigi Pada Anak Usia 6-12 Tahun Di SD Negeri 1 Tamanwinangun Kebumen Tahun 2016. Program Studi S1 Keperawatan Sekolah Tinggi IImu Kesehatan Muhammadiyah Gombong. http://elib.stikesmuhgombong. ac.id/288/1/WINDARTI\%20NI M.\%20A11200847.pdf.

1Dosen Akper Panti Kosala Surakarta

${ }^{2}$ Mahasiswa Akper Panti Kosala

Surakarta 